\title{
Storage of Fresh Yam (Dioscorea alata L.) under Controlled Conditions ${ }^{1}$
}

\author{
M. A. González and A. Collazo de Rivera ${ }^{2}$
}

\section{INTRODUCTION}

Yam (Dioscorea spp.) is one of the most important of the edible root crops grown in Puerto Rico. A variety of Dioscorea alata L., known locally as "Florido" is, among other species, in greatest demand by Puerto Rican consumers.

The yam crop is cultivated on a limited commercial seale by small farmers in the Central Region of Puerto Rico. Production goes to supply the local market as a fresh root crop and to the export market for the continental United States where premium returns are realized.

Although yams are in great demand throughout the year and prices always are high, there has been little or no increase in annual production in Puerto Rico during the last 10 years. The seasonal nature of the crop, and the lack of adequate techniques for storing surplus production, are two factors retarding development.

This root crop has a 4-month rest or dormant period, after which the tubers are no longer in marketable condition. They are planted during February and March at the end of the dormant period and harvested from October to February upon reaching maturity. To avoid price fluctuations due to an oversupplied market, farmers usually leave mature tubers in the ground and harvest several times as required by the demand. Although this practice obviates need for storage facilities, the tubers are exposed unnecessarily to the attacks of yam beetles, termites, and rodents. Harvesting several times also is inconvenient and expensive.

To have yam available during the off season it is necessary either to control sprouting of tubers to plant sceds as needed or to develop a feasible method for prolonged storage of freshly-harvested tubers.

This work was conducted for the purpose of developing a commercial method for the suecessful storage of yam tubers under controlled conditions during the off season. The availability of such a method may well result in an increase in yam production because the surplus then can be properly and profitably handled.

1 Manuscript submitted to Editorial Board July 23, 1971.

2 Technical Director and Assistant Chemist, respectively, Food Technology Laboratory, Agricultural Experiment Station, Mayagüez Campus, University of Puerto Rico, Río Piedras, P.R. 


\section{LITERATURE REVIEW}

Coursey (8) reviewed storage techniques used in different yam-growing areas. In all methods mentioned, the tubers are kept under prevailing ambient conditions following very simple and primitive practices.

In previous studies on the behaviour of $D$. alata yam tubers kept in natural storage (10), it has been observed that sprouting of the tubers at the end of the dormant period is the only limiting factor for prolonged storage under prevailing ambient conditions in Puerto Rico.

The employment of low temperature is a common practice in the prolonged storage of many fruits and vegetables (2). Low temperatures reduce the natural metabolic processes of the produce, retarding ripening, senescence, sprouting, etc. Nevertheless, proper precautions must be observed to avoid chilling damage, especially with high-moisture content products (2). With some tropical crops, critical minimum temperatures as high as $12^{\circ} \mathrm{C}$. $\left(53.6^{\circ} \mathrm{F}\right.$.) may be the case (2). In the extended storage of sweet potatoes, a root crop of tropical origin similar to the yam, temperatures of $12.8^{\circ} \mathrm{C}$. $\left(55^{\circ} \mathrm{F}\right.$.) to $15.6^{\circ} \mathrm{C}$. $\left(60^{\circ} \mathrm{F}\right.$.) are successfully employed (5). The tubers, however, must be subjected first to a curing period prior to cool storage to promote suberization of wounded tissues and thus avoid infections during storage (11).

Few scientists have studied the effect of reduced temperatures on the kecping quality of Dioscorea spp. yams. In experiments conducted in Puerto Rico in 1937 , yams of the species rotundata were kept at $1.1^{\circ} \mathrm{C} .\left(34^{\circ} \mathrm{F}\right.$.) for 10 days (1). At this time the tubers showed a total physiological breakdown. Coursey (7) made similar observations on yam tubers kept in cold ships stores at temperatures below freezing. Czyhrinciw and Jaffe (9) stored D. alata tubers at $3^{\circ} \mathrm{C}$. $\left(37.4^{\circ} \mathrm{F}\right.$.) and $12^{\circ} \mathrm{C}$. $\left(53.6^{\circ} \mathrm{F}\right.$.), and under prevailing ambient conditions, in Venezuela. Tubers kept under low temperatures suffered massive weight losses accompanied by a total physiological breakdown after 3 to 4 weeks. Coursey (6), working with samples of $D$. alata yams made up of five sound tubers each, found that they kept well at $12.5^{\circ} \mathrm{C}$. $\left(54.2^{\circ} \mathrm{F}\right.$.), showed no sign of spoilage after an 8-week storage period, and registered considerably less weight loss than controls stored at room temperat ure. Young (14) suggested $12^{\circ} \mathrm{C} .\left(53.6^{\circ} \mathrm{F}\right.$.) to $16^{\circ} \mathrm{C}$. $\left(60.8^{\circ} \mathrm{F}\right.$ ) as the optimum range for storing Dioscorea spp. tubers.

\section{MATERIALS AND METHODS}

Dioscorea alata yam tubers of the 1968, 1969, and 1970 seasons wore used throughout the course of these studies. The tubers were harvested at a small commercial plantation in the Central Region of Puerto Rico. They were sorted at the Food Technolngy Laboratory where broken tubers were discarded. Only medium-sized roots were selected and these were packed in 
wooden crates ( 40 pounds/crate). The selected yams included sound as well as tubers injured to various degrees. An average of 16 crates were employed in each experiment.

The tubers were stored under two different sets of conditions: controlled and natural ambient prevailing conditions.

The experimental samples kept under controlled conditions were placed in Forma Scientific environmental rooms the interior dimensions of which were 5 feet 2 inches wide, 6 feet 6 inches deep, and 7 feet 1 inch high. The temperature was set at $16^{\circ} \mathrm{C} . \pm 1^{\circ} \mathrm{C}$. $\left(59^{\circ}\right.$ to $62.6^{\circ} \mathrm{F}$.), and the relative humidity kept fairly constant at 70 percent. A continuous inner air flow and a daily renewal of the inner atmosphere by a 15 -minute period of ventilation also were provided. The crates were placed within the chamber, on steel racks which ran parallel to the lateral walls of the rooms.

Control samples were kept under natural storage in a screened, well-ventilated, wooden storage house under prevailing ambient conditions, with temperatures ranging from $21^{\circ}$ to $32^{\circ} \mathrm{C}$. ( $\left(70^{\circ}\right.$ to $90^{\circ} \mathrm{F}$.) and relative humidities of 60 to 95 percent.

To determine the effect of curing prior to storage, freshly harvested tubers were packed in wooden crates and divided into two groups. One group, without previous treatment, was stored in the Forma Scientific environmental room. The second group was cured prior to storage. For curing, the samples were subjected for about 4 days to temperatures ranging from $29.4^{\circ}$ to $32.2^{\circ} \mathrm{C}$. $\left(85^{\circ}\right.$ to $90^{\circ} \mathrm{F}$.) and a relative humidity of 90 to 95 percent until completely suberized. These conditions could be attained both in controlled environmental rooms and in the Food Technology Laboratory under prevailing ambient conditions. The cured tubers then were stored in another environmental room under the same conditions described for the first group. All samples were weighed periodically and inspected for spoilage. Three tubers were taken from each crate at each inspection and sliced open. An index of the degree of spoilage of the stored samples was based on this visual examination. The experiment was repeated using tubers from another harvest.

To determine the effect of storage under controlled conditions on the dormancy of $D$. alata yam, tubers harvested in December 1968, November 1969, January 1970, October, November, and December 1970, and February 1971 were used.

Samples to be stored under controlled conditions also were cured prior to storage. Controls wrere kept in natural storage after boing cured in the same manner as the experimental samples. Records concerning spoilage, sprouting, and weight losses were noted at intervals of all samples.

Both experimental and control samples were cooked and submitted to a 
taste panel for sensory evaluation. Panelists rated samples on the basis of a 9-point hedonic scale, where 9 stands for "like extremely" and 0 for "dislike extremely."

Samples kept under natural and controlled storage conditions also were submitted to chemical evaluation throughout the experimental period. Moisture content was determined by the vacuum oven method (12). Total and reducing sugars were analyzed following the Moyer and Holgate method (13), using invertase for total sugar determination. The Carter and Neubert method (4) was used for starch determinations, but instead of using $6 \mathrm{~N} \mathrm{HClO}_{4}$ for the digestion of the samples, a $7.8 \mathrm{~N}$ concentration was employed. The density of the samples was determined by measuring the volume of water displaced by a known weight of the peeled tuber and the results expressed as $\mathrm{g} . / \mathrm{cc}$.

Texture determinations were performed using a Food Technology Corporation electrical recording and indicating texture instrument with a 3,000pound proving ring and the range set at 1,500 pounds. The plunger was adjusted to a 1-minute stroke, a time force curve was recorded, the maximum force applied was read directly from the chart, and the area under the curve was determined using a planimeter. A standard shear cell packed full was used for each determination. The sample was placed in the cell with the fibers perpendicular to the path of the knives.

\section{RESULTS AND DISCUSSION}

\section{EFFECT OF CURING ON THE KEEPING QUALITY OF YAM TUBERS STORED UNDER CONTROLLED CONDITIONS}

The results obtained from the periodical inspection of cured and uncured tubers of two different harvests stored under controlled conditions showed that uncured samples had suffered damage after 17 days in storage as evidenced by tuber spoilage. The degree of spoilage increased in uncured tubers during storage. No sign of spoilage was noted in the cured samples during the 3-month storage period.

Decay of the uncured samples also was evidenced by weight loss. As shown in figure 1, weight losses of uncured groups were markedly higher than those of cured ones. During the curing period, samples from all harvests studied lost an average of 5 percent of their fresh weight.

The high-spoilage incidence observed in uncured $D$. alata yam stored at $16^{\circ} \mathrm{C}$., 70 percent relative humidity, is in accord with that reported in the literature for untreated Dioscorea spp. tubers stored under reduced temperatures. On the other hand, the results obtained for cured tubers kept stored under similar conditions indicate that a temperature of $16^{\circ} \mathrm{C}$. is safe for keeping yams in storage for prolonged periods. 


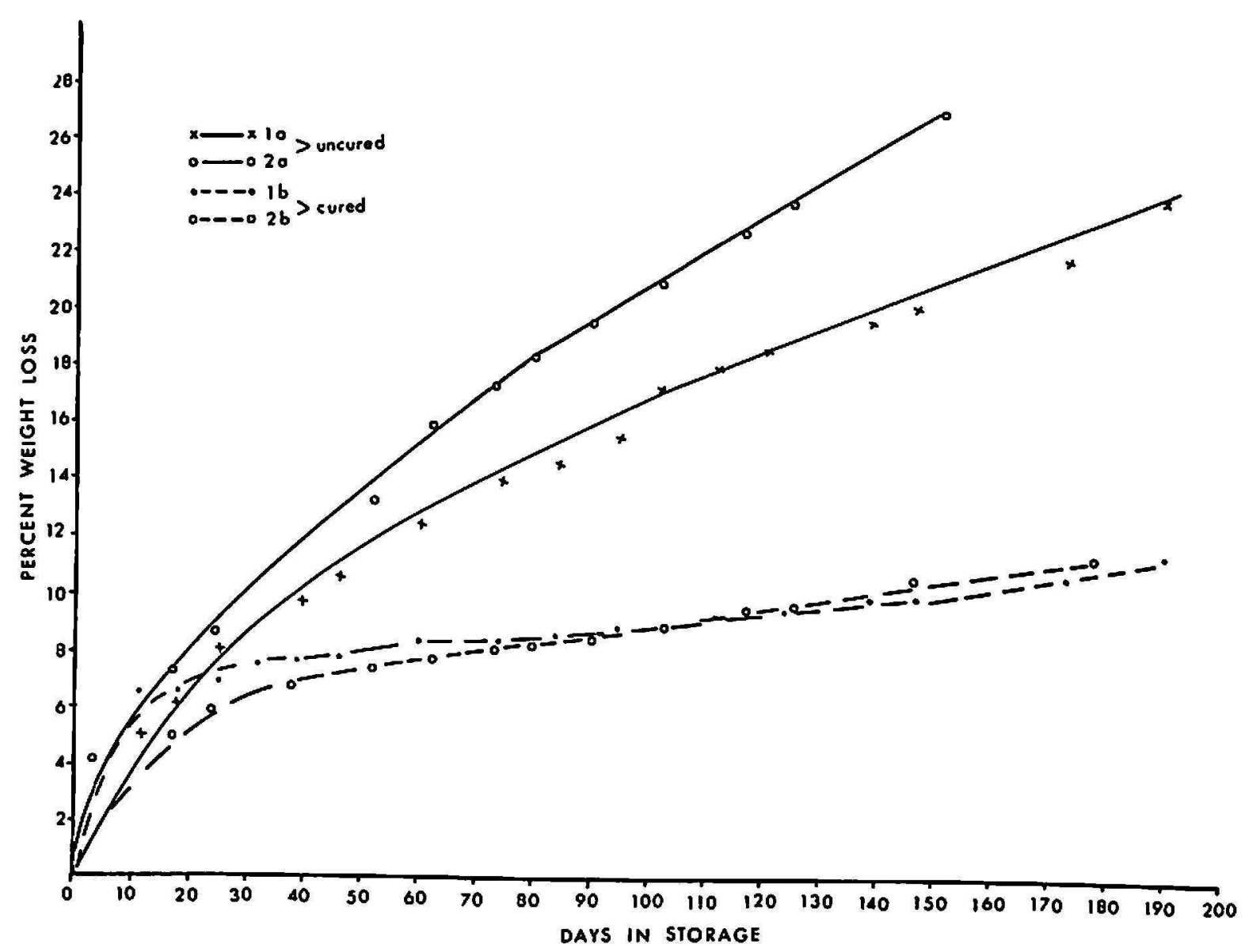

Fig. 1.-Weight losses of cured and uncured Florido yam tubers of two different harvests $(1,2)$ stored under controlled conditions.

EFFECT OF STORAGE UNDER CONTROLLED CONDITIONS ON THE SPROUTING OF CURED YAM TUBERS

Control samples stored under prevailing ambient conditions evidenced the end of their natural dormant period during the interval from January to March regardless of the season or month of harvest. The end of dormancy was marked by the sprouting of the tubers. Although in most cases the first sprouts appeared in January, the bulk of sprouting occurred during February and early March, including the crop harvested in February which sprouted within a week or two.

Records kept periodically for each individual run show moderate weight losses which ranged from 4 to 10 percent until heavy sprouting took place after February. Losses were very high thereafter as shown in figure 2, which presents a set of typical weight loss curves of controls under natural storage.

Experimental samples stored under controlled conditions remained fully dormant until June regardless of the season or month of harvest. The emergence of very small buds was observed at this time. These small buds did not progress noticeably during the 4 to 5 additional months the tubers 


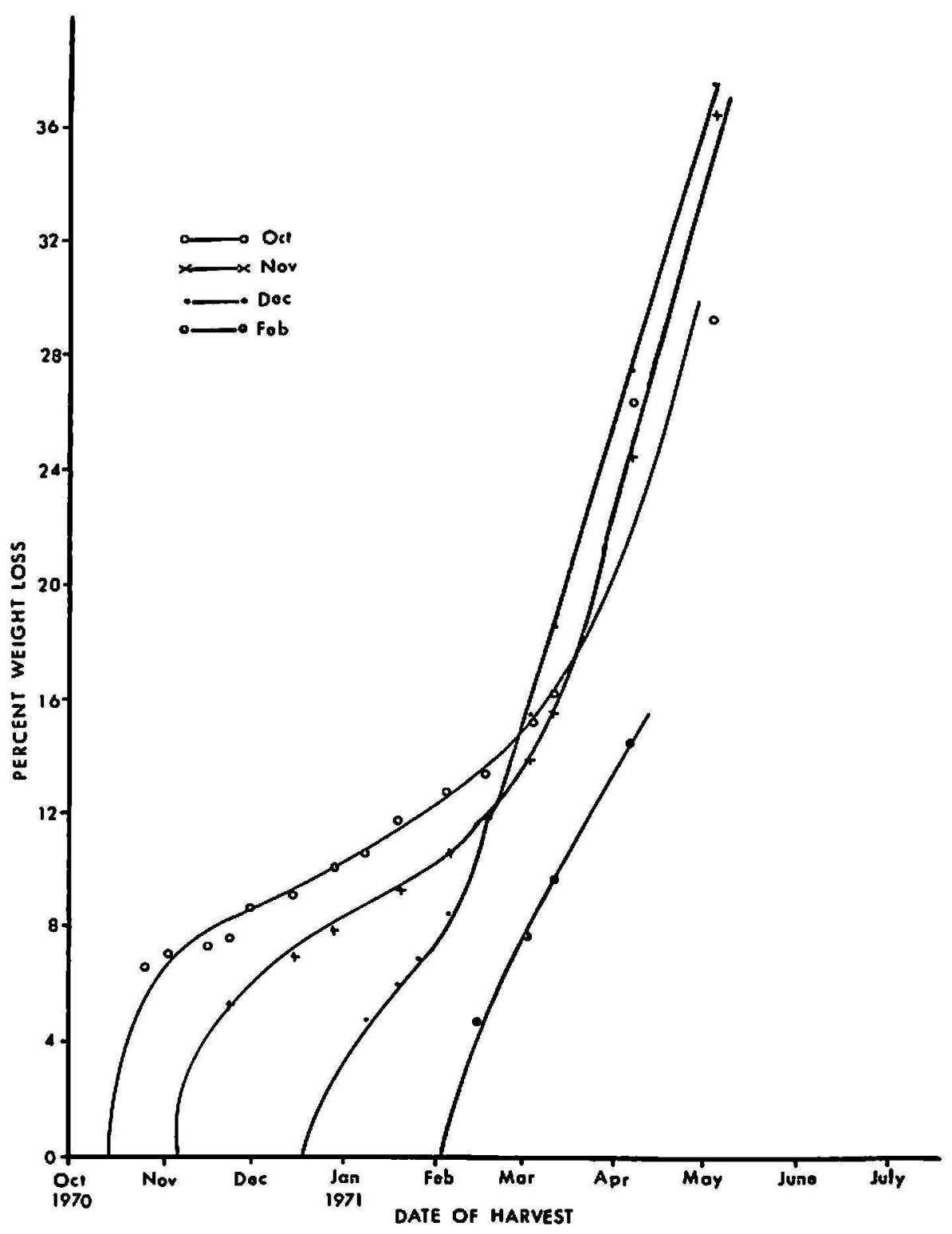

Fra. 2.-Weight losses of cured Florido yam tubers harvested during four different months and stored under natural conditions.

were kept under these conditions but readily developed when the tubers returned to ambient conditions. Figure 3 shows tubers of the same season and harvest, and stored for the same length of time under natural and controlled conditions.

As all experimental samples behaved similarly regardless of their season of harvest, weight loss curves of a representative group corresponding to those presented in figure 2 are shown in figure 4. Losses ranged from 12 to 14 percent when dormancy was broken in June and then continued to increase at a moderate rate, although never as drastic as the weight losses recorded under natural storage.

Samples of the tubers kept under both controlled and natural storage conditions were cooked and submitted to sensory evaluation. Fresh samples 

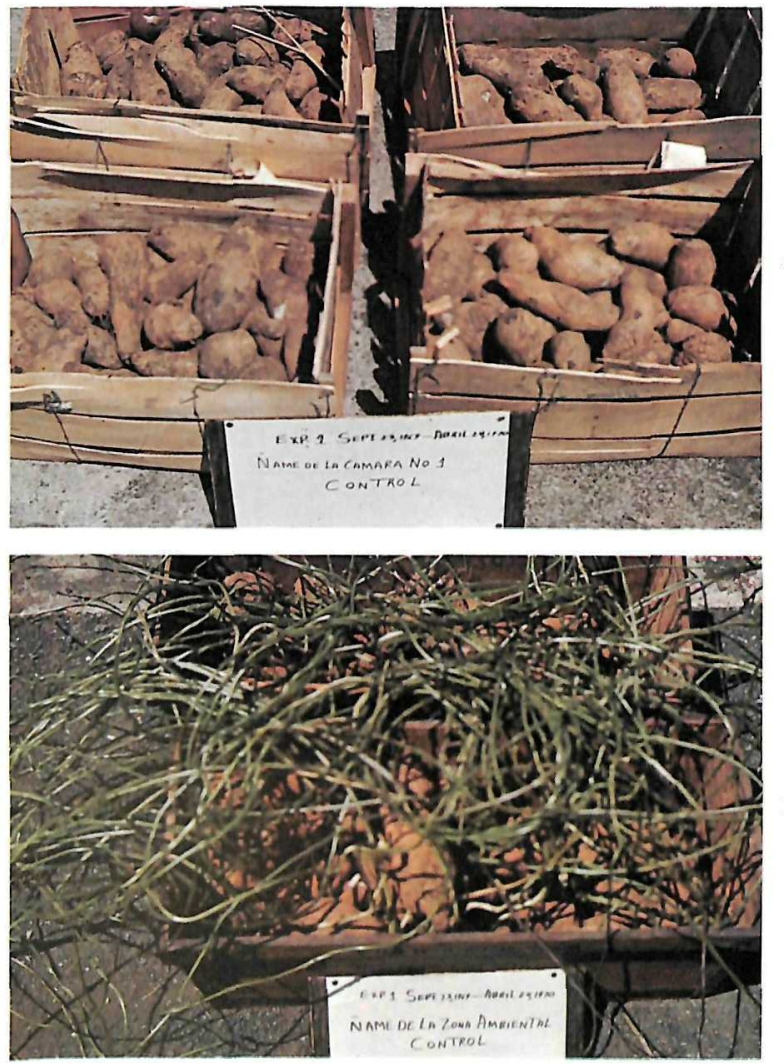

Frg. 3.-Samples of yam stored for 7 months under controlled (A) and natural conditions (B). 


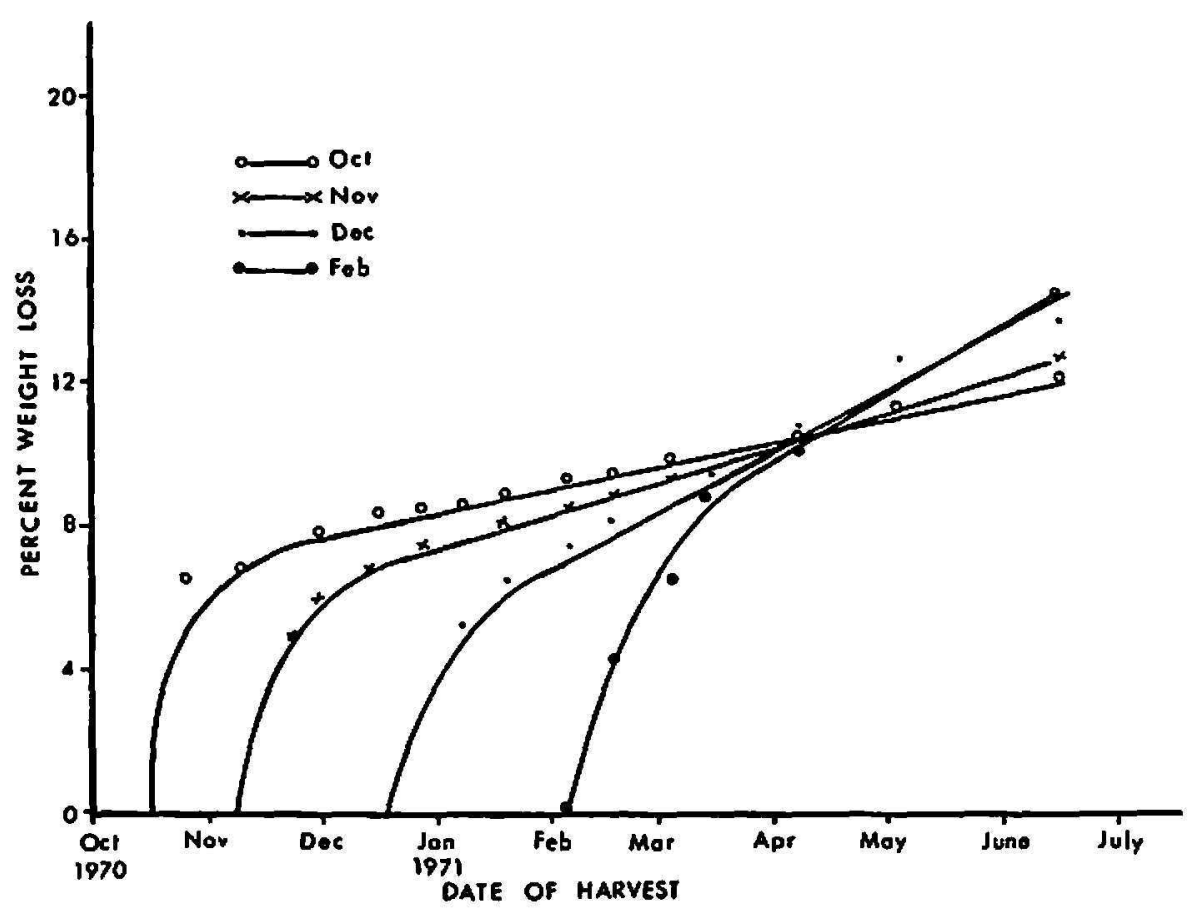

Frg. 4.-Weight losses of cured Florido yam tubers harvested during four different months and stored under controlled conditions.

were rated by the panel 7.0 to 7.7 and 7.5 to 7.9 after 4 months in storage. Thus, no apparent difference was found between the samples regardless of the type of storage, or between tubers of the same sample tasted at different periods during storage.

As shown in table 1, chemical analyses did not indicate any specific pattern of change as to the moisture and starch content. Some indications exist, however, suggesting that the starch content (expressed on a dryweight basis) of the tubers kept under natural storage tends to concentrate, as it increased from 32.2 percent when fresh, to 50.0 percent at the 64th day, then diminished during February (129 days in table 1) and more so later at the end of the dormant period. Starch content in samples under controlled storage remained fairly constant, averaging 35.4 during 7 months of storage. Density, sugars and moisture content varied in both cases, but showed no definite trend throughout the experiment.

In texture measurements, the relation of area under the curve/weight of the samples (table 1) was found to increase during storage, suggesting a hardening of the tubers. The factor increased from $9.0 \times 10^{-3} \mathrm{sq}$. in./g. to $10.1 \times 10^{-3} \mathrm{sq}$. in./g. in samples under natural storage, and from $9.0 \times 10^{-3}$ to $12.0 \times 10^{-3} \mathrm{sq}$. in./g. in experimental samples kept under controlled conditions. 
TABLE 1.-Results of analyses performed on stored D. alata yam tubers

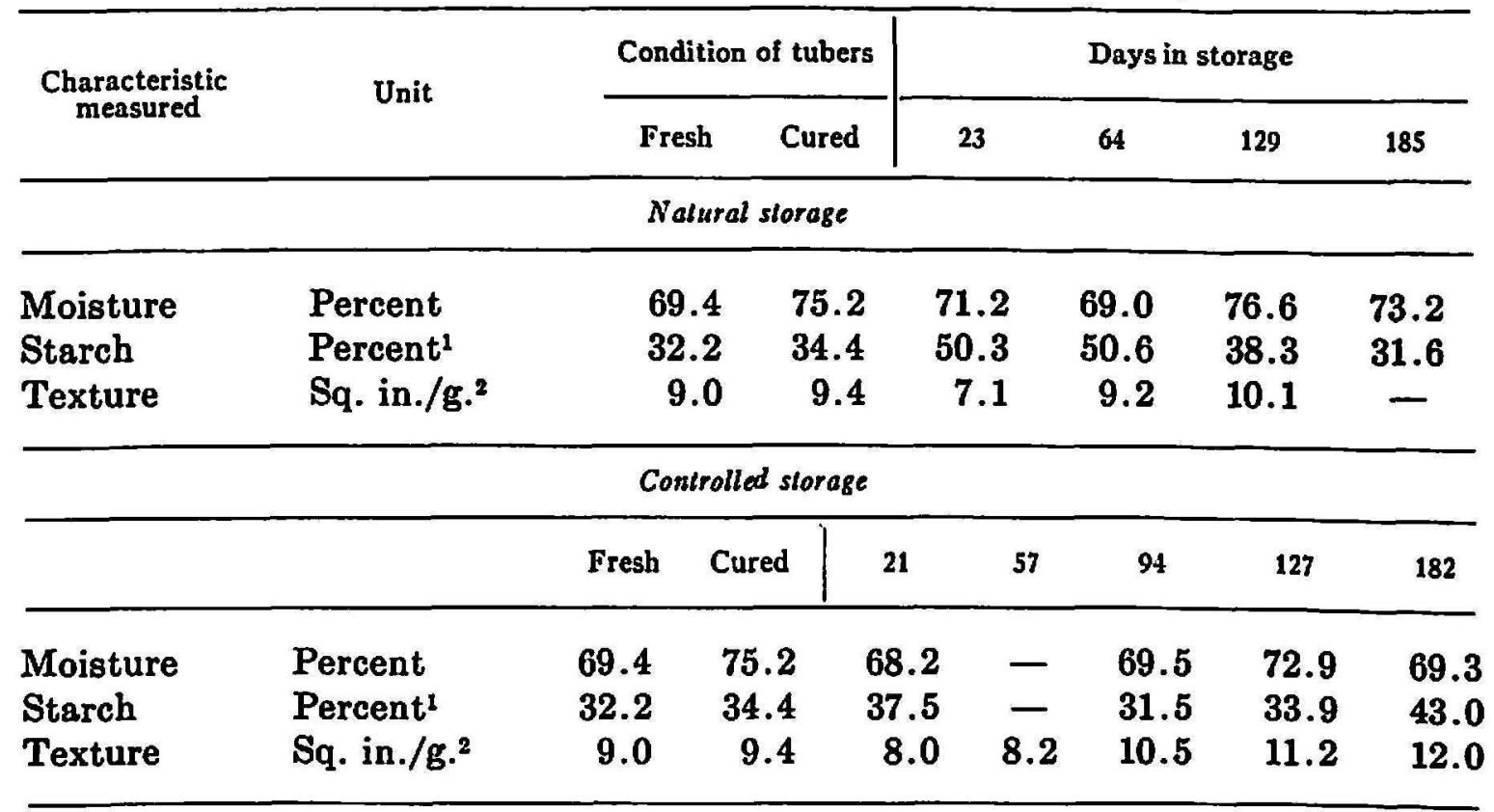

1 Expressed on a dry-weight basis.

2 Values obtained by multiplying the result of the ratio (area under the curve/ weight of sample) times $10^{-3}$ to present the factor as an integral.

The results obtained from these experiments lead to the conclusion that cured Florido yam tubers can be successfully stored at $16^{\circ} \mathrm{C}$., 70 percent relative humidity, in properly ventilated rooms for prolonged periods of time without losses due to spoilage and without detrimental effect to palatability or overall quality. Weight losses were kept fairly low and normal dormancy of the tubers was lengthened for 4 additional months. These factors are of primary importance in providing high-quality tubers for the fresh market and for processing during the off-season. Yam tubers stored under controlled conditions readily sprouted when returned to prevailing ambient conditions after the end of dormancy. This knowledge is of immediate interest to yam growers because it makes possible the planting of seed when desired to harvest during the off-season.

\section{SUMMARY}

Freshly harvested "Florido" yam tubers (a highly desirable variety of the species $D$. alata) were subjected to a temperature of around $32^{\circ} \mathrm{C}$. $\left(90^{\circ} \mathrm{F}\right.$.) and a relative humidity of 90 percent. Wounded tissues were suberized in about 4 days. This curing may be accomplished either in controlled environmental rooms or under tropical prevailing ambient conditions. The formation of the cork tissue during suberization protects tubers from infection by microorganisms if stored under reduced temperatures. 
Cured and uncured tubers were stored in a properly ventilated Forma Scientific room at $16^{\circ} \mathrm{C}$. $\pm 1^{\circ}\left(59^{\circ}\right.$ to $62.9^{\circ} \mathrm{F}$.), and a relative humidity of 70 percent. Uncured samples suffered high losses due to physiological breakdown as well as markedly higher weight losses than similarly handled cured ones which showed no signs of internal decay during the storage period.

Cured tubers kept under conditions noted above, at temperatures below those prevailing in tropical areas, had the dormant period lengthened by 4 additional months. High-quality tubers can be provided by this means for the fresh market and for processing during the off-season. Although the yam tubers hardened slightly during storage, weight losses were kept at a fairly low level and the palatability of the tubers remained very high, as determined by sensory evaluation.

\section{RESUMEN}

Names de la variedad Florido (D. alata) de reciente cosecha y almacenados a una temperatura de aproximadamente $32^{\circ} \mathrm{C}$. $\left(90^{\circ} \mathrm{F}\right.$.) y una humedad relativa de 90 por ciento cicatrizaron sus lesiones por completo en alrededor de 4 días. La cura puede llevarse a cabo en el Trópico en cámaras controladas o bajo condiciones ambientales normales. La cura o suberización de las áreas lesionadas proteje los tubérculos de posibles infecciones al almacenarse a temperaturas bajas. Tubérculos de esta variedad curados y sin curar, fueron almacenados a $16^{\circ} \mathrm{C} . \pm 1^{\circ}\left(59^{\circ}\right.$ a $62.9^{\circ} \mathrm{F}$.) y una humedad relativa de 70 por ciento en una cámara bien ventilada. Los ñames que no fueron curados previamente se deterioraron con rapidez, sufriendo también grandes pérdidas en peso, mientras que los curados se mantuvieron en buenas condiciones por la duración del estudio.

El ñame curado y así almacenado prolongó su período de inactividad 4 meses adicionales. Esto permitiría mantener una existencia de ñame de alta calidad fuera de temporada, tanto para el consumo del producto fresco como para fines industriales. Aunque duranet el almacenamiento el ñame se endureció un poco, las pérdidas en peso fueron relativamente bajas y el sabor de los tubérculos muy aceptable, según se demostró mediante una prueba sensorial.

\section{LITERATURE CITED}

1. Anonymous, USDA Annual Report of the Puerto Rico Expt. Sta., 42-9, 1937.

2. Borgstrom, G., Principles of Food Science, The Macmillan Company, New York, N.Y., 1: 148, 1968.

3. Campbell, J. S., Chukwueke, V. O., Teriba, F. A., and Sho-A-Shu, H. V., Some physiological investigations into the white Lisbon yam (Dioscorea alata L.). II. Growth period and out off-season production, Empire J. Exp. Agr. 30 (119): 232-38, 1962.

4. Carter, G. H. and Neubert, A. M., Rapid determination of starch in apples, J. Agr. Food Chem. 2 (21): 1070-72, 1954.

5. Cooley, J. G., Kushman, L. J., and Smart, H. F., Effect of temperature and duration of storage on quality of stored sweet potatoes, Econ. Bot. 8: 21-8, 1954.

6. Coursey, D. G., Low temperature injuries in yams, J. Food Tech. 3: 143-50, 1968. 
7. Coursey, D. G., Yams, Longmans, Green and Co. Ltd., London W1, England, 188-89, 1967.

8. Coursey, D. G., Yam Storage, I: A review of yam storage practices and of information on storage losses, J. Stored Prod. Res. 2: 229-44, 1967.

9. Czyhrinciw, N. and Jaffe, W., Modificaciones químicas durante la conservación de raices y tubérculos, Arch. Venez. Nutr. 2 (1): 49-67, 1951.

10. González, M. A. and Collazo de Rivera, A. L., Unpubl.

11. Lutz, J.M., Influence of temperature and length of curing period on keeping quality of Porto Rico sweet potatoes, Proc. Am. Soc. Hort. Sci. 59: 421-25, 1952.

12. Methods of Analysis of the Association of Official Agricultural Chemists, 9th. ed., Washington, D. C., p. 272, 1960.

13. Moyer, J. C. and Holgate, K. C., Determination of alcohol insoluble solids and sugar content of vegetables, Anal. Chem. 20 (5): 472-74, 1948.

14. Young, R. A., Cultivation of the true yams in the Gulf region, USDA Bull. No. $1167,1923$. 